\title{
Mating behavior and female accompaniment in the whiptail lizard Cnemidophorus ocellifer (Squamata, Teiidae) in the Caatinga region of northeastern Brazil
}

\author{
Leonardo Barros Ribeiro ${ }^{1,2,3,5}$, Melissa Gogliath ${ }^{1,4}$, \\ Raul Fernandes Dantas de Sales ${ }^{1,4}$ \& Eliza Maria Xavier Freire $e^{1,2,4}$ \\ ${ }^{1}$ Laboratório de Herpetologia, Departamento de Botânica, Ecologia e Zoologia, Centro de Biociências, \\ Universidade Federal do Rio Grande do Norte - UFRN, Av. Senador Salgado Filho, 3000, \\ Campus Universitário Lagoa Nova, CEP 59072-970, Natal, RN, Brasil \\ ${ }^{2}$ Programa Regional de Pós-graduação em Desenvolvimento e Meio Ambiente, Centro de Biociências, \\ Universidade Federal do Rio Grande do Norte - UFRN, Av. Senador Salgado Filho, 3000, \\ Campus Universitário Lagoa Nova, CEP 59072-970, Natal, RN, Brasil \\ ${ }^{3}$ Centro de Conservação e Manejo de Fauna da Caatinga - CEMAFAUNA-CAATINGA, \\ Universidade Federal do Vale do São Francisco - UNIVASF, Campus Ciências Agrárias, Colegiado de \\ Ciências Biológicas, Rod. BR 407, Km 12, Lote 543, s/n, C1, CEP 56300-990, Petrolina, PE, Brasil \\ ${ }^{4}$ Programa de Pós-graduação em Psicobiologia, Departamento de Fisiologia, Centro de Biociências, \\ Universidade Federal do Rio Grande do Norte - UFRN, Av. Senador Salgado Filho, 3000, \\ Campus Universitário Lagoa Nova, CEP 59078-970, Natal, RN, Brasil \\ ${ }^{5}$ Corresponding author: Leonardo Barros Ribeiro, e-mail: leonardo.ribeiro@univasf.edu.br
}

\begin{abstract}
RIBEIRO, L.B., GOGLIATH, M., SALES, R.F.D. \& FREIRE, E.M.X. Mating behavior and female accompaniment in the whiptail lizard Cnemidophorus ocellifer (Squamata, Teiidae) in the Caatinga region of northeastern Brazil. Biota Neotrop. 11(4): http://www.biotaneotropica.org.br/v11n4/en/abstract?shortcommunication+bn01611042011
\end{abstract}

\begin{abstract}
We report here a set of observations on mating behavior and female accompaniment by the whiptail lizard Cnemidophorus ocellifer in an area of Caatinga (xerophilous open forests) in the state of Rio Grande do Norte, northeastern Brazil. We observed a stationary male lizard performing repeated vibratory movements of the pelvis and tail base upon the sandy soil. Since that male was in front of a burrow in which a female of the same species was sheltered, we hypothesize that this behavior may be part of a courtship display. We continued the observation and later, when the female emerged from the burrow, the male climbed on her and the copulation occurred. The incident of accompaniment observed was characterized by one male continuously accompanying a female during foraging. Plausible functional explanations for a male accompany a female include mating guarding, post-copulatory courtship, and sperm loading. By accompanying females, males would be guaranteeing insemination by multiple copulation and stimulation of the female, and protecting their paternity by chasing away other males, diminishing the chances of extra-pair copulations.

Keywords: behavior, courtship, mating, reproduction, teiids, Caatinga.
\end{abstract}

RIBEIRO, L.B., GOGLIATH, M., SALES, R.F.D. \& FREIRE, E.M.X. Comportamento de acasalamento e acompanhamento da fêmea no lagarto-da-cauda-de-chicote Cnemidophorus ocellifer (Squamata, Teiidae) na Caatinga, nordeste do Brasil. Biota Neotrop. 11(4): http://www.biotaneotropica.org.br/v11n4/pt/abstract?shortcommunication+bn01611042011

Resumo: Nós relatamos uma série de observações sobre o comportamento de acasalamento e acompanhamento da fêmea no lagarto-da-cauda-de-chicote Cnemidophorus ocellifer em uma área de Caatinga no estado do Rio Grande do Norte, Brasil. Nós observamos um macho estacionário realizando movimentos vibratórios da pélvis e base da cauda sobre o solo arenoso. Uma vez que o macho estava em frente à abertura de uma toca onde uma fêmea se encontrava abrigada, nós sugerimos que esse comportamento faz parte da exibição de corte. Continuamos a observação e posteriormente, quando a fêmea saiu da toca, o macho engajou-se em montá-la e progrediu para uma cópula. A ocasião de acompanhamento da fêmea foi caracterizada por um macho continuamente acompanhando uma fêmea durante o forrageamento. Explicações funcionais plausíveis para uma fêmea ser acompanhada por um macho incluem guarda de parceiro, corte pós-copulatória e fornecimento de estoque de esperma. Ao acompanhar as fêmeas, os machos estariam garantindo a inseminação através de múltiplas cópulas e estimulação pós-copulatória da fêmea, e protegendo a paternidade afugentando outros machos, diminuindo as chances de cópulas extra-par. Palavras-chave: comportamento, corte, acasalamento, reprodução, lagartos teiídeos, Caatinga. 


\section{Introduction}

Courtship and mating behavior in lizards are characterized by a set of casual events (e.g. Vitt 1983, Costa et al. 2010, Gogliath et al. 2010). Some of the behavior related to sex recognition, courtship, and copulation that is observed in both natural and enclosed lizard populations, includes cloacal rubbing in teiids (Carpenter 1962), head nodding in tropidurids (Carpenter 1977), dewlap extension in polychrotids (Jenssen 1977), and skin darkening in leiosaurids (Lima $\&$ Sousa 2006).

The most commonly reported mating system in lizards is polygyny (Zug et al. 2001). In territorial species, males can occupy territories containing the home ranges of several females, leading to a territorial polygynous mating system (Bull 2000, Ribeiro et al. 2009). However, some males may be monogamous if their poorer territories attract fewer females (e.g. Panov \& Zykova 1993, LemosEspinal et al. 1997). Because males usually arrange their territories to enclose the female's territory and exclude other males from their own territories, females have little opportunity to see more than one male at a time; thus, females tend to be monogamous (Stamps 1983). In non-territorial lizards, however, polygyny often is sequential, with males usually searching for females, and staying with them for various lengths of time after successful mating (Anderson \& Vitt 1990, Olsson 1993, Censky 1995, Cooper \& Vitt 1997, Olsson \& Shine 1998). Because females of these species have the opportunity to mate with several males, the primary mechanism available to males to ensure paternity is to accompany the female and guard her from access by other males (Bull 2000). Thus, the tendency of males to maintain close proximity to females after copulation (post-copulatory female accompaniment; Zaldívar-Rae \& Drummond 2007) often is regarded as mate guarding (Bull 2000, Zaldívar-Rae \& Drummond 2007). By accompanying females after copulation, males are protecting their paternity by reducing the opportunity of females to copulate with others males (mate-guarding hypothesis; Beecher \& Beecher (1979), Birkhead (1979)). However, alternate, non-exclusive functional hypotheses for accompaniment are applicable to lizard mating systems (reviewed in Zaldívar-Rae \& Drummond 2007). The male may accompany a female to stimulate her, increasing the probability of the female using his sperm to fertilize eggs (post-copulatory courtship hypothesis; Alcock (1994), Eberhard (1996)), or to sustain elevated rates of copulation, swamping rival sperm or providing an adequate supply of his own sperm to the female (sperm-loading hypothesis; Alcock (1994)).

Teiidae comprises non-territorial lizards distributed throughout the Americas, from northern United States to Chile and Argentina (Zug et al. 2001). Teiids are heliothermic, active foragers, and commonly abundant in open habitats. Sexual dimorphism in size and shape is widespread in the family, with males attaining larger body sizes than females and having relatively larger heads, a trend that is attributed to sexual selection (Anderson \& Vitt 1990, Censky 1995). Among teiids, the cnemidophorines (whiptail lizards) occupy various habitats in the Americas, with the genus Cnemidophorus occurring throughout South America (Reeder et al. 2002). The whiptail lizard Cnemidophorus ocellifer (Spix, 1825) is widely distributed in Brazil, occurring in the Cerrado of central Brazil, in the Caatinga of northeastern Brazil, and in restingas along the northeastern Brazilian coast (Vanzolini et al. 1980, Menezes et al. 2011). It is a conspicuous member of lizard assemblages from open habitats, and especially common in sandy and rupicolous areas (Vitt 1995, Mesquita \& Colli 2003a). Individuals commonly are active during the hottest hours of the day (Vitt 1995, Mesquita \& Colli 2003b), and the species seems to have a continuous reproductive cycle in the Caatinga (Vitt 1983).
The social interactions of teiids have proven to be difficult to study in the wild because of the lizard's active mode of foraging, which tends to lead to enlarged home ranges (Censky 1995), and strong wariness, which is linked to foraging mode and predator escape tactic (Vitt \& Price 1982). Thus, studies reporting social interactions in teiids often are based on casual observations (e.g. Vitt 1983, Costa et al. 2010), and the few studies that investigated social interactions quantitatively were performed mainly with insular populations (Censky 1995, 1997, Baird et al. 2003, Zaldívar-Rae \& Drummond 2007, Ancona et al. 2010), in which the lizards often occur in elevated densities, facilitating observations by investigators. Little is known about courtship and mating behavior of mainland teiid species, especially Cnemidophorus. Herein, we report a set of observations about mating behavior and female accompaniment in the whiptail lizard Cnemidophorus ocellifer (Squamata, Teiidae) from a Caatinga area of northeastern Brazil.

\section{Material and Methods}

All observations reported here were obtained while we conducted fieldwork for another research project to assess the role of microhabitat use in structuring the lizard assemblage from a site (06 $08^{\circ}$ ' 14" S and 36 44' 81' W, datum: WGS84, $680 \mathrm{~m}$ above sea level) in the Caatinga in the municipality of Tenente Laurentino Cruz, Rio Grande do Norte, Brazil. The study area (locally known as "Nascimento") has mainly subarboreal vegetation, with "jurema preta" trees (Mimosa tenuiflora (Willd.) [Fabaceae-Mimosoideae]) as the dominant plant species. The soil is sandy, grayish white, and covered with a thin layer of leaf litter. The local climate is semiarid (BSHw according to Köppen), hot and dry, with rainfall of $706 \mathrm{~mm} /$ year, mean temperature of $26.6{ }^{\circ} \mathrm{C}$ and humidity of $65 \%$ RH (Beltrão et al. 2005).

On two different occasions during the evaluation of microhabitat use by the lizards, LBR and MG found one adult male of $C$. ocellifer exhibiting courtship behavior. Thereafter, the individuals were monitored for the description of the behavioral repertoire. All behavioral observations were recorded in a notebook, and photos and videos were taken using a digital camera (Sony Cyber-shot DSC-H50).

\section{Results}

At 1420 hours on 10 July 2010 during a line transect survey, an adult male $C$. ocellifer was sighted moving in the leaf litter. After the lizard moved about $1 \mathrm{~m}$, he reached a hillock of sandy soil covered by sparse herbaceous plants. There were five holes in the ground near the lizard. The male initiated cloacal rubbing against the ground in front of one of these holes. In performing cloacal rubbing, he wagged his pelvic region in a movement involving the posterior trunk region, pelvis, hind legs, and base of the tail. The lizard moved forward 10$15 \mathrm{~cm}$, then reversed direction and returned to his original position, continuing the wagging movements. These movements appeared to depict a figure eight. He then slid over the hole opening three times, undulating while he moved, and after each of these movements, stopped and uncovered the opening of the burrow, digging with his front legs. On two occasions during cloacal rubbing, the male entered the burrow up to his hind legs (Figure 1a); his pulling movements seemed to suggest that he was attempting to remove the female from the hole. After $2 \min 50 \mathrm{~s}$ of cloacal rubbing, the female left the burrow and the male then climbed onto her back scratching her with his forelimbs (Figure 1b). He attemped to grab hold of her skin several times, during which the female tried once to return to the burrow, until he grabbed the skin on her neck with his jaws, thereby gaining a hold on the female (Figure 1c). After 2 minutes of subjugating the 

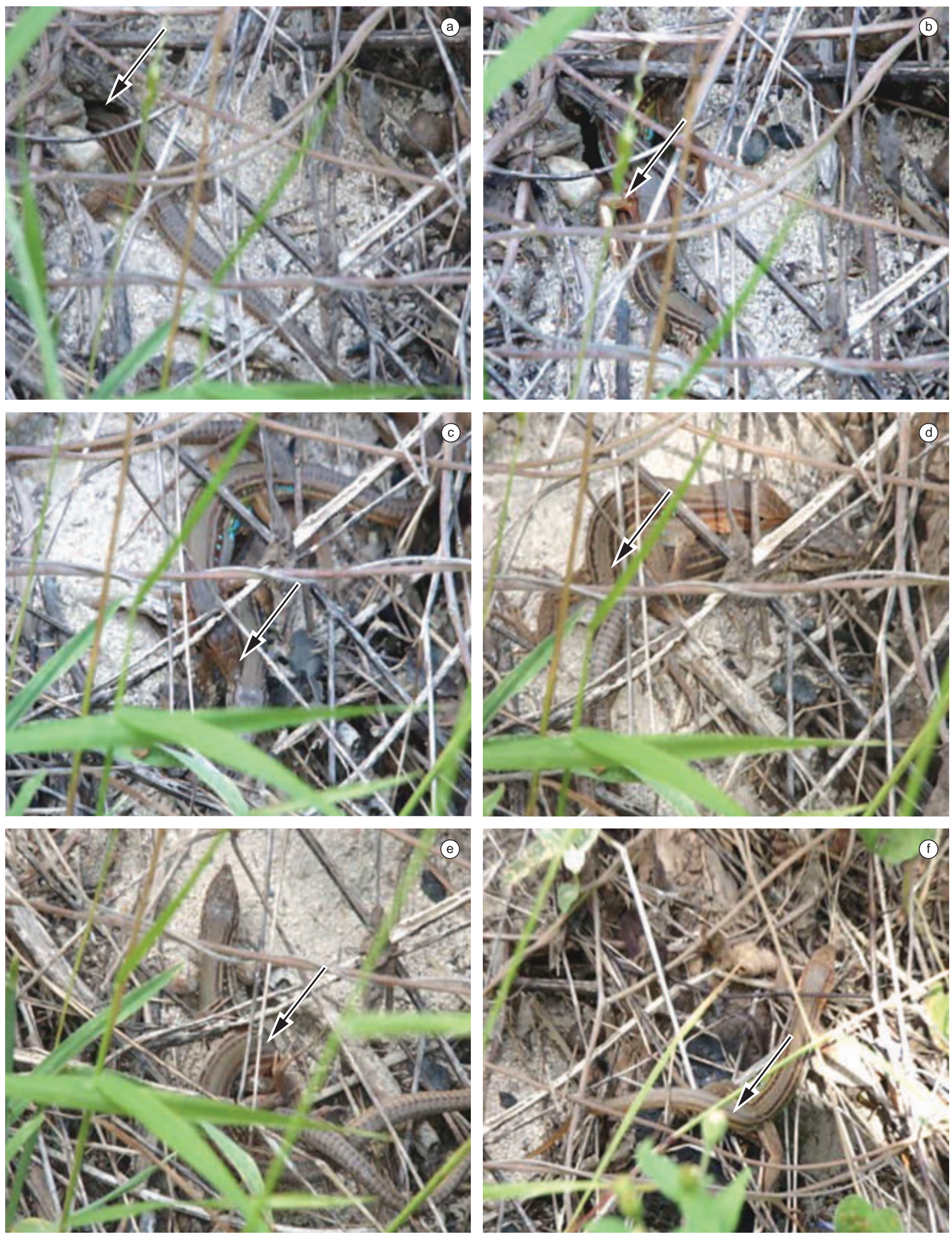

Figure 1. Mating behavior in Cnemidophorus ocellifer. a) male attempting to remove a female from her burrow; b) moment at which the female leaves the burrow and the male climbs onto her back; c) male mounting the female's dorsum with a neck-bite hold and front-leg hold on the female's trunk; d) male maneuvering his tail under that of his mate, bringing his cloaca into contact with hers; e) male during hemipenis intromission into the female's cloaca, assuming a highly arched position across her back ("doughnut posture"); f) male moving away after copulation, holding his tail upright because his hemipenis was still everted. Video frames by M. Gogliath. 
female, the male mounted her, persistently moving his pelvic region toward that of the female, bringing his cloaca into contact with hers (Figure 1d). After intromission of the hemipenis, the male shifted his jaws from the female's neck to her pelvic region, assuming a highly arched position across her back (Figure 1e). He maintained this position for $1 \mathrm{~min} 05 \mathrm{~s}$, during which time convulsive jerks occurred in his pelvic region, presumably indicating ejaculation. The female remained passive during copulation and immediately returned to the burrow upon its conclusion. In contrast, the male dismounted and moved away, lifting his pelvic region and tail off the ground, with his hemipenis still everted (Figure 1f). Finally, he began to forage within a few minutes after leaving the female. The entire behavioral repertoire and copulation lasted about $6 \mathrm{~min} 20 \mathrm{~s}$.

At 1515 hours on 26 October 2010, an adult male C. ocellifer was sighted near the opening of a hole in the ground (ca. $25 \mathrm{~mm}$ in diameter). On this occasion, the male lizard also performed cloacal rubbing in front of the burrow; the female emerged from the burrow after a few minutes, but he did not attempt to mount her. Instead, both began to forage together in the surroundings of the burrow. Every time that the female moved, the male followed her (Figure 2a). During these periods, he often maintained physical contact, covering her hind legs and base of tail region (Figure $2 b$ ). The male also performed a series of tongue-flicks on the female's back during this activity. During the observation, the female twice executed a sequence of two or three sinuous, figure-eight movements, which were confined to a small area, and after which, the female moved away. After each movement, the male remained motionless for a few moments and then resumed following her while foraging. After 45 minutes and nearly $15 \mathrm{~m}$ from their initial positions, the pair entered in dense underbrush, where we could not continue to observe them. While we observed the pair, there was no agonistic encounter between the accompanying male and other males for access or copula with the female.

\section{Discussion}

Our casual observations of courtship and mating, including the cloacal rubbing, copulation, and the male accompaniment of females in Cnemidophorus ocellifer are relevant to our understanding of behavioral reproductive patterns in teiid lizards, because there are so few reports on these activities in the literature. Ecological features of C. ocellifer are relatively well studied (e.g. Vitt 1995, Mesquita \& Colli 2003a, Santana et al. 2010, Menezes \& Rocha
2011, Menezes et al. 2011), and although some studies have already explored some aspects of the reproductive biology of this species, such as duration of reproductive cycle and clutch size (Vitt 1983, Mesquita $\&$ Colli 2003a), information about reproductive behavior is scarce. Vitt (1983) studied reproduction in a population of $C$. ocellifer from a Caatinga area in Pernambuco, Brazil, and observed mating behavior on three occasions. In contrast to our observation of courtship and copulation in C. oceliffer, in which the females were in burrows, Vitt (1983) reported that males pursued foraging females, but he did not mention female accompaniment after copulation. Two conditional mating strategies have been described for teiid males (Zaldívar-Rae \& Drummond 2007). 1) In consensual copulations, the male courts the female, slowly circling her for several minutes, then straddling her and copulating; this strategy is often performed by a male companion, and thus is linked to accompaniment. 2) Opportunistic copulations are not preceded by courtship, and are characterized by a male chasing and holding a foraging female, and not accompanying her after copulation (Zaldívar-Rae \& Drummond 2007). Possibly, the observations reported by Vitt (1983) were opportunistic copulations, whereas ours, in which the male engaged in courtship, represented a consensual copulation performed by a male companion. Postcopulatory accompaniment did not occur after copulation because the female returned to her burrow.

Among behaviors exhibited by $C$. ocellifer during courtship, cloacal rubbing also is known for a North American whiptail, Aspidoscelis sexlineata (Linnaeus, 1766); Carpenter (1962) suggested that this behavior represents auto-stimulation by the male when he is aware that a female is nearby. In addition, our finding that male cloacal rubbing does not always precede copulation suggests that this behavior may also play a role in male-female communication through a combination of signals, including tactile (substrate vibration), auditory (sound produced by stirring the underbrush and grains of sand against leaves), visual (the male passes over the burrow opening so that the female is able to see him) and chemical (by means of femoral pores) clues. Other male courtship behavior (e.g. grasping the female by the skin of her neck and scratching her sides with his fore and hind limbs) seems to pacify the female, thereby ensuring the male of successful copulation (Crews 1987).

Crews (1987) coined the term "doughnut posture" for the moment at which the male everts the hemipenis into the female and transfers his neck-bite hold to the female's pelvic region in the North American Aspidoscelis inornata (Baird, 1859). This behavior characterizes
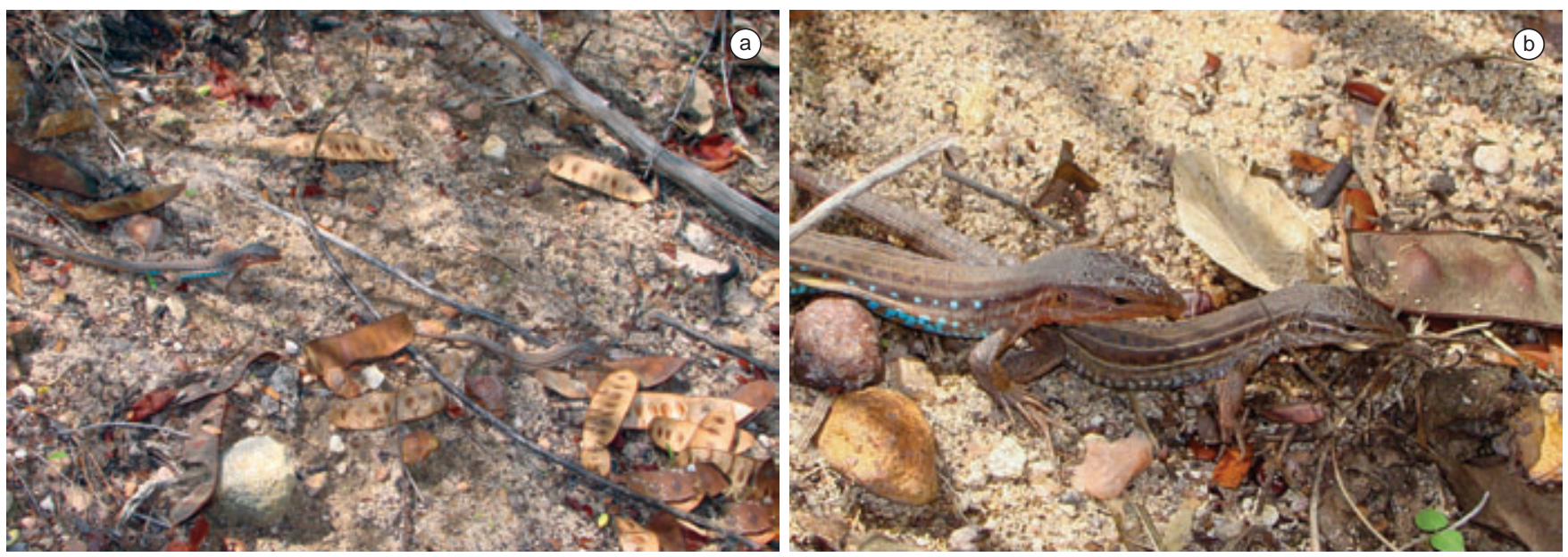

Figure 2. Female accompaniment in Cnemidophorus ocellifer. a) male accompanying one female while both were foraging on the ground; b) male on the female's dorsum, an approach in which he probes her body with his tongue, a probable mechanism to access her reproductive condition. Photos by L.B. Ribeiro. 
the ejaculation phase. The courtship ritual between females in the unisexual species Aspidoscelis uniparens (Wright \& Lowe, 1965) is almost identical to that described here for $C$. ocellifer and also reported for A. inornata (Crews 1987). The only difference is that all A. uniparens are morphological females, and the female that assumes the "male" position during pseudocopulation cannot perform hemipenis intromission. According to Crews (1987), in both bisexual and unisexual species, copulation and pseudocopulation stimulate the female to ovulate. In A. uniparens, the ovarian cycle defines whether the female will behave as a female or as a "male" in pseudocopulation.

To date, female accompaniment in teiids is known to occur in a few species of the genera Aspidoscelis (Anderson \& Vitt 1990, Zaldívar-Rae \& Drummond 2007, Ancona et al. 2010) and Ameiva (Censky 1995). Based on these reports, Zaldívar-Rae et al. (2008) remarked that this behavioral trait seems to be widespread in mating systems of teiids. Our observations for $C$. ocellifer expand the number of species known to exhibit this behavior, but we recognize that further studies are necessary to understand better the functions of accompaniment in this species, including analysis of costs and benefits for males and females, and evaluation of all hypotheses proposed to explain this behavioral trait, as did Zaldívar-Rae \& Drummond (2007) and Ancona et al. (2010) for the Mexican whiptail Aspidoscelis costatus (Cope, 1878).

Our observations of males interacting with females in burrows are similar to those reported by Censky $(1995,1997)$ in the teiid Ameiva plei (Duméril \& Bibron, 1839). In this Caribbean taxon, males accompany females for 2-4 days, corresponding to the duration of their receptive period. Moreover, males compete for access to females, the larger male usually taking precedence to the smaller. In this case, the male accompanies the female throughout the day, and usually copulates with her when she emerges and also before she returns to her burrow (Censky 1995, 1997). The female then enters the burrow and the male often continues to defend the opening for about $30 \mathrm{~min}$ before returning to his own burrow. The next day, the male waits for the female at the entrance to her burrow. When she emerges another day of accompaniment begins, with the male driving away any other male that attempts to approach her. Based on these observations, Censky (1995) interpreted accompaniment as mate guarding.

In the Mexican whiptail A. costatus, males accompany receptive periovulatory females for 1-5 days. During this period, male companions follow, court and copulate repeatedly with the accompanied female, and aggressively repel approaching males (Zaldívar-Rae \& Drummond 2007). Because accompaniment in this species reduces the occurrence of extra-pair copulations, as in A. plei, the authors also interpreted this behavior as mate guarding. Moreover, as males court and copulate repeatedly with the females that they accompany, the accompaniment is also consistent with the sperm-loading and post-copulatory courtship hypotheses (Alcock 1994). Ancona et al. (2010) showed that mate guarding is costly for males in this population of $A$. costatus because of simultaneous reduction in energy intake and increased expenditure on aggression. The high costs to males through diminished survivor explain why accompaniment generally occurs only when females are receptive (Ancona et al. 2010).

Although we have not seen agonistic interactions between the male companion and other males in the accompaniment episode observed in $C$. ocellifer, we think that accompaniment may also function as mate guarding in this species, as it does in Ameiva plei and Aspidoscelis costatus. Moreover, the other functional hypotheses for accompaniment mentioned early may also be supported in C. ocellifer. As verified by Zaldívar-Rae \& Drummond (2007) in A. costatus, accompaniment may benefit males through copulatory access, post-copulatory courtship, sperm loading, and diminishing extra-pair copulations. In addition, accompaniment may also benefit females, through post-copulatory courtship, access to copulations with high-quality males, and fertilization assurance. For females, accompaniment may also be beneficial in that it protects them against harassment by other males, optimizing their foraging time (Censky 1997).

Our observations of courtship patterns and copulation in C. ocellifer most likely reflect a common phylogenetic origin among whiptail lizards, and are reported here as a contribution to the knowledge of the natural history and behavior of this lizard, broadly distributed in Neotropical habitats. Most observations on the reproductive behavior of Cnemidophorus in South America are sporadic and opportunistic, such as the ones related here and those reported by Vitt (1983). Nevertheless, this kind of information will contribute to an understanding the strategies and tactics related to reproduction in this interesting lineage of lizards. We recommend further studies addressing the role of behavioral displays in courtship and reproductive success, and investigating the existence of accompaniment behavior in other teiids, as well as the functions of this behavior in reproductive success of males and females.

\section{Acknowledgements}

We thank the Programa PELD/CNPq - Caatinga: Estrutura e Funcionamento and the municipal government of Tenente Laurentino Cruz for logistical support. Linda Trueb and one anonymous reviewer provided helpful comments on an early draft of this manuscript. This study was supported by doctorate and postdoctorate fellowships from Coordenação de Aperfeiçoamento de Pessoal de Nivel Superior (CAPES) awarded to M. Gogliath and L.B. Ribeiro, respectively, and by research fellowships granted by CNPq to R.F.D. Sales (process 109115/2010-4) and E.M.X. Freire (process 304077/2008-9).

\section{References}

ALCOCK, J. 1994. Postinsemination associations between males and females in insects: the mate guarding hypothesis. Ann. Rev. Entomol. 39:1-21. http://dx.doi.org/10.1146/annurev.en.39.010194.000245

ANCONA, S., DRUMMOND, H. \& ZALDÍVAR-RAE, J. 2010. Male whiptail lizards adjust energetically costly mate guarding to male-male competition and female reproductive value. Anim. Behav. 79:75-82. http://dx.doi. org/10.1016/j.anbehav.2009.10.005

ANDERSON, R.A. \& VITT, L.J. 1990. Sexual selection versus alternative causes of sexual dimorphism in teiid lizards. Oecologia 84:145-157.

BAIRD, T.A., VITT, L.J., BAIRD, T.D., COOPER, W.E., CALDWELL, J.P. \& PÉREZ-MELADO, V. 2003. Social behavior and sexual dimorphism in the Bonaire whiptail, Cnemidophorus murinus (Squamata: Teiidae): the role of sexual selection. Can. J. Zool. 81:1781-1790. http://dx.doi. org/10.1139/z03-178

BEECHER, M.D. \& BEECHER, I.M. 1979. Sociobiology of bank swallows: reproductive strategy of the male. Science 205:1282-1285. PMid:17750153. http://dx.doi.org/10.1126/science.205.4412.1282

BIRKHEAD, T.R. 1979. Mate guarding in the magpie Pica pica. Anim. Behav. 27:866-974. http://dx.doi.org/10.1016/0003-3472(79)90024-1

BELTRÃO, B.A., ROCHA, D.E.G.A., MASCARENHAS, J.C., SOUZA JUNIOR, L.C., PIRES, S.T.M. \& CARVALHO, V.G.D. 2005. Diagnóstico do município de Tenente Laurentino Cruz, estado do Rio Grande do Norte. Serviço Geológico do Brasil, Recife.

BULL, C.M. 2000. Monogamy in lizards. Behav. Proc. 51:7-20. http://dx.doi. org/10.1016/S0376-6357(00)00115-7

CARPENTER, C.C. 1962. Patterns of behavior in two Oklahoma lizards. Am. Midl. Nat. 67:132-151. http://dx.doi.org/10.2307/2422824

CARPENTER, C.C. 1977. The aggressive displays of three species of South American iguanid lizards of the genus Tropidurus. Herpetologica 33:285-289. 
CENSKY, E.J. 1995. Mating strategy and reproductive success in the teiid lizard, Ameiva plei. Behaviour 132:529-557. http://dx.doi. org/10.1163/156853995X00199

CENSKY, E.J. 1997. Female mate choice in the non-territorial lizard Ameiva plei (Teiidae). Behav. Ecol. Sociobiol. 40:221-225. http://dx.doi. org/10.1007/s002650050336

CREWS, D. 1987. Courtship in unisexual lizards: a model for brain evolution. Sci. Am. 257:72-77. http://dx.doi.org/10.1038/scientificamerican1287-116

COOPER, W.E. \& VITT, L.J. 1997. Maximizing male reproductive success in the broad-headed skink (Eumeces laticeps): preliminary evidence for mate guarding, size-assortative pairing, and opportunistic extra-pair mating. Amphibia-Reptilia 18:59-73. http://dx.doi.org/10.1163/156853897X00314

COSTA, H.C., SILVA, E.T., CAMPOS, P.S., OLIVEIRA, M.P.C., NUNES, A.V. \& CAMPOS, P.S. 2010. The corpse bride: a case of Davian behaviour in the Green Ameiva (Ameiva ameiva) in southeastern Brazil. Herpetol. Notes 3:79-83.

EBERHARD, W.G. 1996. Female control: sexual selection by cryptic female choice. Princeton University Press, Princeton.

GOGLIATH, M., RIBEIRO, L.B. \& FREIRE, E.M.X. 2010. Forced copulation attempt in the Blue-tailed Lizard, Micrablepharus maximiliani (Reinhardt \& Luetken, 1862) (Squamata, Gymnophthalmidae) in the Caatinga of northeastern Brazil. Biota Neotrop. 10:347-350. http://dx.doi. org/10.1590/S1676-06032010000400040

JENSSEN, T.A. 1977. Evolution of Anoline lizard display behavior. Am. Zool. 17:203-215.

LEMOS-ESPINAL, J.A., SMITH, G.R. \& BALLINGER, R.E. 1997. Neonatefemale associations in Xenosaurus newmanorum: a case of parental care in a lizard? Herpetol. Rev. 28:22-23.

LIMA, A.F.B. \& SOUSA, B.M. 2006. Court and copulation behaviors of Enyalius perditus Jackson, 1978 (Squamata, Leiosauridae) in captivity conditions. Rev. Bras. Zooc. 8:193-197.

MENEZES, V.A. \& ROCHA, C.F.D. 2011. Thermal ecology of five Cnemidophorus species (Squamata: Teiidae) in east coast of Brazil. J. Therm. Biol. 36:232-238. http://dx.doi.org/10.1016/j.jtherbio.2011.03.004

MENEZES, V.A., VAN SLUYS, M., FONTES, A.F. \& ROCHA, C.F.D. 2011. Living in a caatinga-rocky field transitional habitat: ecological aspects of the whiptail lizard Cnemidophorus ocellifer (Teiidae) in northeastern Brazil. Zoologia 28:8-16.

MESQUITA, D.O. \& COLLI, G.R. 2003a. The ecology of Cnemidophorus ocellifer (Squamata, Teiidae) in a Neotropical Savanna. J. Herpetol. 37:498-509. http://dx.doi.org/10.1670/179-02A

MESQUITA, D.O. \& COLLI, G.R. 2003b. Geographical variation in the ecology of populations of some Brazilian species of Cnemidophorus (Squamata, Teiidae). Copeia 2003:285-298. http://dx.doi.org/10.1643/00458511(2003)003[0285:GVITEO]2.0.CO;2
OLSSON, M. 1993. Male preference for large females and assortative mating for body size in the sand lizard (Lacerta agilis). Behav. Ecol. Sociobiol. 32:337-341. http://dx.doi.org/10.1007/BF00183789

OLSSON, M. \& SHINE, R. 1998. Chemosensory mate recognition may facilitate prolonged mate guarding by male snow skinks, Niveoscincus microlepidus. Behav. Ecol. Sociobiol. 43:359-363. http://dx.doi. org/10.1007/s002650050502

PANOV, E.N. \& ZYGOTA, L.Y. 1993. Social organization and demography of Caucasian agama, Stellio caucasius (Squamata, Agamidae). Zool. Zh. 72:74-93.

REEDER, T.W., COLE, C.J. \& DESSAUER, H.C. 2002. Phylogenetic relationships of whiptail lizards of the genus Cnemidophorus (Squamata: Teiidae): a test of monophyly, reevaluation of karyotypic evolution, and review of hybrid origins. Am. Mus. Novit. 3365:1-61. http://dx.doi. org/10.1206/0003-0082(2002)365\%3C0001:PROWLO\%3E2.0.CO;2

RIBEIRO, L.B., SOUSA, B.M. \& GOMIDES, S.C. 2009. Range structure, microhabitat use, and activity patterns of the saxicolous lizard Tropidurus torquatus (Tropiduridae) on a rock outcrop in Minas Gerais, Brazil. Rev. Chil. Hist. Nat. 82:577-588. http://dx.doi.org/10.4067/S0716078X2009000400011

SANTANA, G.G., VASCONCELLOS, A., GADELHA, Y.E.A., VIEIRA, W.L.S., ALMEIDA, W.O., NÓBREGA, R.P. \& ALVES, R.R.N. 2010. Feeding habits, sexual dimorphism and size at maturity of the lizard Cnemidophorus ocellifer (Spix, 1825)(Teiidae) in a reforested resting habitat in northeastern Brazil. Braz. J. Biol. 70:631-637. http://dx.doi. org/10.1590/S1519-69842010005000006

STAMPS, J.A. 1983. Sexual selection, sexual dimorphism, and territoriality. In Lizard Ecology. Studies of a Model Organism (R.B. Huey, E.R. Pianka \& T.W. Schoener, ed). Harvard University Press, Cambridge, p.169-204.

VANZOLINI, P.E., RAMOS-COSTA, A.M.M. \& VITT, L.J. 1980. Répteis das Caatingas. Academia Brasileira de Ciências, Rio de Janeiro.

VITT, L.J. 1983. Reproduction and sexual dimorphism in the tropical teiid lizard Cnemidophorus ocellifer. Copeia 1983:359-366. http://dx.doi. org/10.2307/1444378

VITT, L.J. 1995. The ecology of tropical lizards in the caatinga of northeast Brazil. Occ. Pap. Okla. Mus. Nat. Hist. 1:1-29.

VITT, L.J. \& PRICE, H.J. 1982. Ecological and evolutionary determinants of relative clutch mass in lizards. Herpetologica 38:237-255.

ZALDÍVAR-RAE, J. \& DRUMMOND, H. 2007. Female accompaniment by male whiptail lizards: is it mate guarding? Behaviour 144:1383-1402. http://dx.doi.org/10.1163/156853907782418187

ZALDÍVAR-RAE, J., DRUMMOND, H., ANCONA-MARTÍNEZ, S., MANRÍQUEZ-MORÁN, N.L. \& MÉNDEZ-DE LA CRUZ, F.R. 2008. Seasonal breeding in the western Mexican whiptail lizard Aspidoscelis costata on Isla Isabel, Nayarit, Mexico. Southwest. Nat. 53:175-184. http://dx.doi.org/10.1894/0038-4909(2008)53[175:SBITWM]2.0.CO;2

ZUG, G.R., VITT, L.J. \& CALDWELL, J.P. 2001. Herpetology - An Introductory Biology of Amphibians and Reptiles. Academic Press, San Diego. 